\title{
Online emotional
} support: discourse functionalities on Chilean Facebook pages by patients with chronic pain*

Apoio emocional online: funcionalidades do discurso nas páginas chilenas do Facebook por pacientes com dor crônica

Mariana PASCUAL (PUC-Chile) Mariana.pascual@uc.cl

Recebido em: 31 de jan. de 2021. Aceito em: 25 de jun. de 2021.

*This project was funded by FONDECYT Grant 11190133. Discurso y salud: la construcción discursiva del dolor en pacientes con enfermedades crónicas.

PASCUAL, Mariana. Online emotional support: discourse functionalities on Chilean Facebook pages by patients with chronic pain. Entrepalavras, Fortaleza, v. 11, n. 3, e2298, p. 277-295, set.-dez./2021. DOI: 10.22168/22376321-32298.

Abstract: This research analyzed an emerging and rapidly increasing type of communication from the perspective of its social purpose (MARTIN; ROSE, 2008). We focus on comments from three public Facebook webpages by endometriosis patients to determine the interpersonal configuration of the texts produced. The corpus comprises 7230 comments written over a period of over four years. The data were analyzed in terms of the interpersonal configurations based on the System of Appraisal (MARTIN; WHITE, 2005). Results indicate that Facebook pages corresponding to patient interaction perform a variety of social purposes, thus, different discourse genres. The main genres identified refer to the exchange of affective meanings, aiming at consolidating a sense of community and align its members, by exchanging emotional support. Other genres aimed at the exchange of information, focusing on specific details of the condition. A third type of genre identified was of the story type, narrating the patients' experiences with endometriosis and the resulting chronic pain. Results point to clearly different discoursal configurations, with a marked interpersonal functionality. This highly interactive form of digital 
V. $11(3)$ 277-295 set-dez 2021 communication seems to have partly replaced patient-patient interactions given in face-to-face modalities in the past, in clubs, churches, hospitals or other support groups. However, it has expanded the typical narrative nature and purpose of the original social practice, to include genuine exchanges of information and emotion which seems to have been facilitated by the distant and more impersonal type of participation stemming from online communication.

Keywords: Discourse genres. Digital communication. System of Appraisal.

Resumo: Esta pesquisa analisou um tipo de comunicação emergente e em rápido crescimento, sob a perspectiva de sua finalidade social (MARTIN; ROSE, 2008). Concentramo-nos em comentários de três páginas públicas do Facebook por pacientes com endometriose para determinar a configuração interpessoal dos textos produzidos. O corpus compreende 7.230 comentários escritos ao longo de um período de quatro anos. Os dados foram analisados quanto à sua finalidade social, identificandose configurações interpessoais emergentes do Sistema de Avaliatividade (MARTIN; WHITE, 2005). Os resultados indicam que as páginas do Facebook que correspondem à interação do paciente realizam diferentes finalidades sociais, portanto, gêneros discursivos distintos: um que visa à troca de informações e que enfoca detalhes específicos da doença; outro que serve ao propósito de narrar aos pacientes experiências com endometriose e a dor crônica resultante; e outro com o propósito de brindar e receber apoio emocional. Esta forma altamente interativa de comunicação digital aparentemente substitui de modo parcial as interações paciente-paciente que eram dadas em modalidades face a face no passado, em clubes sociais, igrejas, hospitais ou outros grupos de apoio. No entanto, essa forma de suporte parece ter expandido a natureza narrativa típica do gênero e seu propósito para incluir trocas genuínas de informações e emoções. Isso tem sido facilitado pelo tipo de participação distante e mais impessoal que decorre da comunicação virtual.

Palavras-chave: Gêneros discursivos. Comunicação digital. Sistema de Avaliatividade.

\section{Introduction}

This study focuses on a controversial, highly relevant and frequently used digital platform in most modern societies: Facebook. Our interest lies on health communication and on the specific characteristics that it takes under this digital environment. Language studies such as the one we present here, grounded on the perspective offered by Systemic Functional Linguistics (SFL), place special emphasis on the notion of language as a constituent part of the individual, and of discourse as inexorably related to social life (HALLIDAY, 1978; HALLIDAY; MATTHIESSEN, 2014). Thus, from this standpoint, social changes affect language and vice-versa. Health communication is not an exception, and new technologies have brought along forms of interaction that have not yet been fully explored.

Studies on health communication from a discourse perspective have increased rapidly over the last decades (see, for example, a very complete review by Hamilton and Chou, 2016). The long-lasting 
paradigm placing health as a purely biological phenomenon has been replaced by an awareness of the significance and impact of communication on people's health. Research on chronic disease has covered three main foci: patient-health provider interaction, specific aspects of chronic diseases and the experience of living with the disease (ANTÓN; GOERING, 2015).

Doctor-patient interaction and the genres that construe their experience have dominated the arena of discourse studies from the onset of this new comprehensive view (see, among many others, the seminal studies by Wodak, 1996; von Raffler-Engel, 1989). Nevertheless, several social actors are involved in health services, not only doctors and patients but also nurses, caregivers, patients' families, hospital staff among various others, whose function is to care for the health of the population.

Some studies have turned their attention to other types of health-related communication, such as the narrative discourse produced by patients with chronic diseases, such as endometriosis (BULLO, 2018, 2019; PASCUAL, 2019, 2020; PASCUAL; DÍAZ ALEGRÍA, 2021). One type of patient-patient interaction has proved to be highly beneficial: interaction taking place in support groups, which has shown to be of significant help in reducing patients' fatigue, depression, confusion and tension and, overall, has improved the life quality of people who take part in those groups (SPIEGEL et al. 1989, ROTHIER DUARTE; BATISTA MELO, 2019). Technology has facilitated the creation and rapid expansion of online support groups, with specific characteristics and functionalities, which have not yet been fully explored.

Hence, the objective of this study is to determine the interpersonal configuration of the comments produced on three public Facebook webpages by endometriosis patients as a means to understand the functionalities that are enacted in this type of communication. Our analysis is based on the principles of Systemic Functional Linguistics, and, specifically on the view of genre from the perspective of the Sydney School.

\section{On social media interaction and health communication}

Face-to-face interaction has been partially replaced, or complemented by digital communication, made possible by the presence of several social network sites, such as Facebook. Kaplan and Haenlein 
v. 11 (3) 277-295 set-dez 2021

(2010) provided one of the most cited definitions of social media. For these authors, the social media constitute "a group of Internet-based applications that build on the ideological and technological foundations of Web 2.0, and that allow the creation and exchange of user-generated content". The authors also claim that "content and applications are no longer created by individuals, but instead are continuously modified by all users in a participatory and collaboratory fashion" (p. 61). Following their initiative, but from a sociolinguistic perspective, scholars like Leppanen, Westinen and Kytola (2017) published a widely recognized series of studies on identifications and diversity on the social media, using ethnographic approaches. However, it seems that the analysis of media interaction is approached in a contrastive manner, taking faceto-face interaction as an unavoidable point of contrast.

The specific characteristics of the new types of communication have been addressed by studies such as the one by Agha (2007), to explain the linguistic phenomenon of "enregisterment", through which linguistic and other semiotic resources become recognizable to the members of a given culture. This idea was expanded by Stæhr (2015), who determined some of the specifics of written and oral language practices in Facebook interaction.

In health communication from a linguistic perspective, studies have been conducted on social media support groups over the last 15 years (see, for example, MUSTAFA; SHORT; FAN, 2015; PARTRIDGE et al., 2018; KOBALL et al., 2017; JACOBS et al; 2016). They agree on the fact that the social media have re-shaped health communication, and constitute an important aspect in patients' lives, though the quality and format of the information they provide are poorly understood and a source of frequent questioning.

Sharing narratives with other patients who suffer the same pathology has always been an important aspect of human experience, providing support, orientation, and comfort for those who must undergo similar experiences. This can be observed in the development of support groups over time in history. Clear cases are church groups, social clubs, hospital groups and numerous other associations of individuals towards the protection and improvement of their health, and this notion includes support groups related to alcoholism, obesity, smoking, and a complete range of pathologies (MUSTAFA; SHORT; FAN, 2015).

Our interest relates to support groups for chronic disease patients; specifically, for women in their reproductive years who suffer 
endometriosis, a condition characterized by severe pain, and accounts for nearly half the cases of infertility (BULLO, 2019, PASCUAL, 2019, 2020). From a discourse perspective, this study aims at describing the functionalities constructed in Facebook support groups by Chilean women who suffer this chronic disease with a focus on their interpersonal configuration.

\section{Genres from an SFL perspective: The Sydney School}

The School of linguistics that has developed a theoretical and analytic model for the analysis of genre following the principles for discourse analysis on an SFL basis is known as The Sydney School (MARTIN 2000, 2004; MARTIN; ROSE, 2008, MARTIN; WHITE, 2005). Its most influential scholar is James Martin, who followed the foundations established by Halliday (1985) considering language as a stratified semiotic system which realizes social context. This idea was originally proposed in the early 6os by Hjelmslev (1961), and it implies a specific organization of the language in layers of abstraction, or strata. As all semiotic systems, language presents a level of content and a level of expression, the latter including specific physical elements that instantiate the more abstract levels.

Regarding the level of content, Halliday proposed two strata for its organization: lexicogrammar and discourse semantics. It is at this level that context operates. In Halliday's terms, context is "the total environment in which a text unfolds" (1978, p. 5), and it does so by shaping language production (MARTIN, 1992). It is precisely in this area that the Sydney School has been highly productive, setting the grounds for extensive research and further theoretical development. Genre and register constitute levels of abstraction, the layers of context in which language functions. The former constitutes the focus of this study.

In an early definition, Martin conceptualized genre as "a staged, goal-oriented social process" (1986, p. 246), manifested in the register as the variables of field, mode and tenor (MARTIN, 1992). Over the decades, the theory has been refined and expanded, but the basic principles have remained unchanged, thanks to its proven potential for the analysis of actual discourses of various types. In 2007 Martin and Rose claimed that "[t]he stages of a genre are relatively stable components of its organization, that we can recognize in some form in 
v. 11 (3)

277-295

set-dez

2021

instance after instance of the genre, such as the Orientation, Incident and Interpretation stages of an exemplum (MARTIN; ROSE, 2007, p. 10).

This approach to discourse distinguishes the Sydney School from other research traditions. The model proposed by these authors (MARTIN; ROSE, 2007) also comprises families of genres, which share linguistic resources and a broad social purpose, and can be recognized by the members of a given culture. Figure 1 presents an adapted version of the families of genres proposed.

Figure 1 - The family of genres

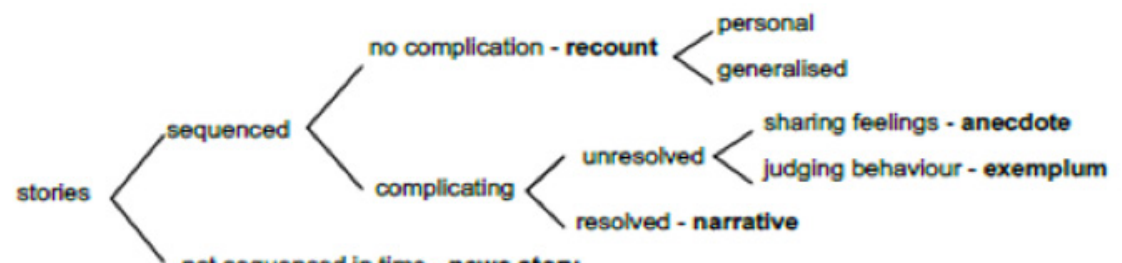

not sequenced in time - news story

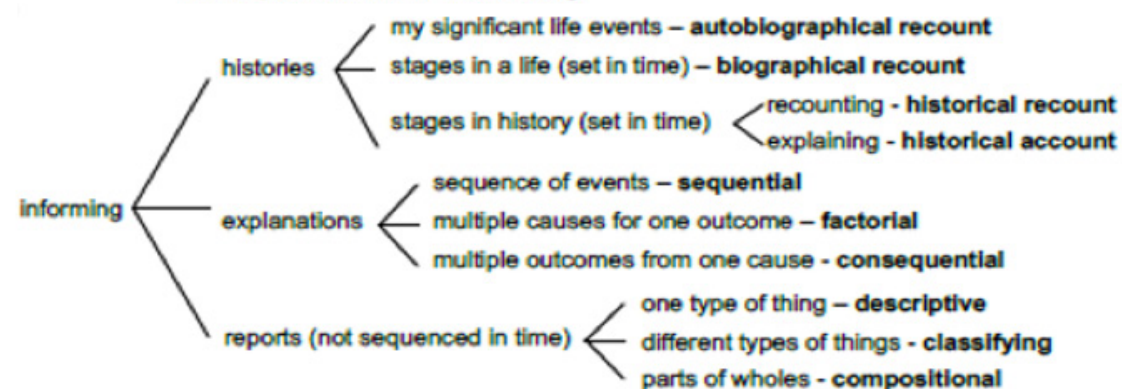

parts of wholes - compositional
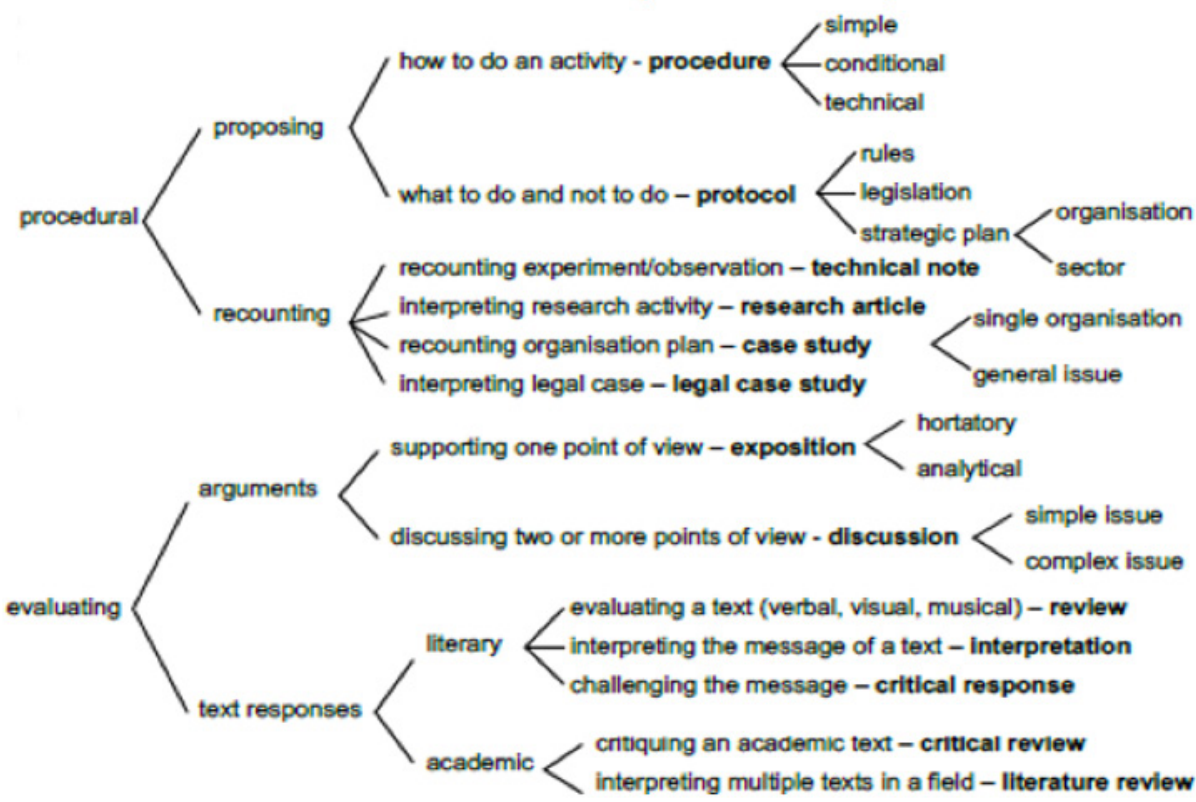

Source: Adapted from Martin and Rose (2008).

One of the most frequent genres in every culture is stories. They are present in every society and have been acknowledged as one of 
the most productive cultural means for transmitting and consolidating social values. The relevance of the genre should not be underestimated. Modern language studies on narratives started relatively early in the 1960s, with the classic work by Labov and Waletzky (1967), who identified a basic structure of Complication^ Resolution. However, this model of spoken narratives has been criticized for neglecting samples which did not follow this pattern as being "ill-formed" (ROSE, 2011). Nevertheless, it constitutes a landmark in narrative research, which set the foundations for a plethora of studies on this genre.

In support groups aiming at helping those undergoing a health endangering condition such as endometriosis, it would be reasonable to expect exchanges of personal narratives as one of their main practices, in line with what used to be observed in traditional face-to-face support groups. In consequence, the configurations from the story genres presented in Figure 2 might well be expected.

Figure 2 - Story genres

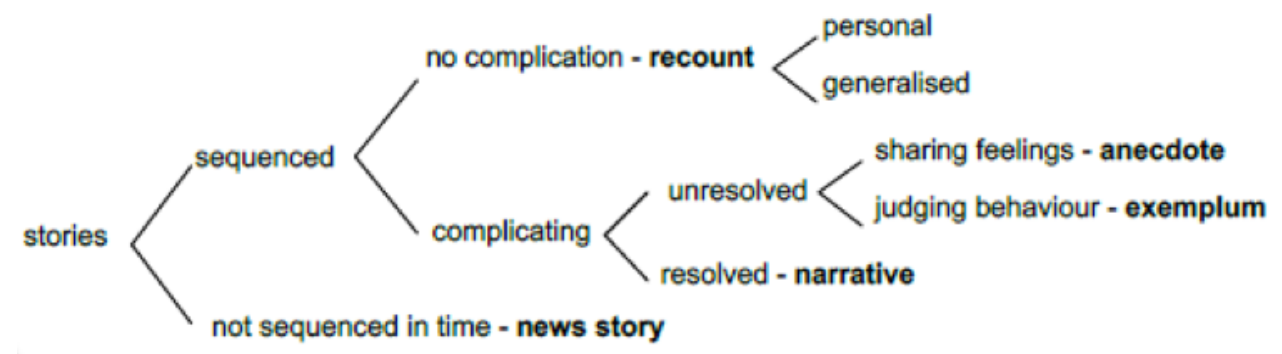

Source: Adapted from Rose (2011).

Each genre in the family is recognized by its configuration in terms of the types of experience that they construe, the expected response, and the attitude to which they are usually associated. A Facebook comment such as the following, taken from our corpus, may illustrate a typical instance of story genre of the autobiographical type, a series of events with no specific complicating event:

I have been treated, I had surgery with a specialized doctor, but it didn't work. Two months after the surgery I had a hemorrhagic cyst, I consulted another professional that only told me that endometriosis had come back very soon, but I think my surgery failed because the pains never stopped. ${ }^{1}$ (C163).

\footnotetext{
1 Original Spanish version: Me he tratado, me operé con un doctor especialista, pero no resultó. En 2 meses de operada tuve un quiste hemorrágico, pasé a otro profesional que solo me dijo que la endometriosis volvió muy pronto, pero creo que mi cirugía falla porque nunca
} 
V. 11 (3) 277-295 set-dez 2021

This Facebook comment illustrates a recount, a sequenced personal story, in which the speaker narrates significant events in her life in a chronological order. This is the genre that might be expected from a Facebook page created by patients with endometriosis, the gynecological condition under analysis.

Along these lines and taking into consideration that the organization of each genre can be distinguished by recurrent local patterns, a series of phases may be expected in each genre, each with a typical function, as Table 1 shows.

Table 1 - Typical phases in the story genres and functionality associated

\begin{tabular}{ll}
\hline Phase & Functionality in the narrative \\
\hline setting & presenting context (identities, activities, locations) \\
\hline description & evoking context (sensual imagery) \\
\hline events & expectant events \\
\hline problem & counterexpectant creating tension \\
\hline solution & counterexpectant releasing tension \\
\hline result & material outcome \\
\hline reaction & behavioural/attitudinal outcome \\
\hline comment & intruding narrator's comments \\
\hline reflection & intruding participants' thoughts \\
\hline Source: Adapted from Rose (2011).
\end{tabular}

Thus, in the example above "two months after the surgery" constitutes setting, "I have been treated" construes events, "it didn't work" realizes a problem phase, and so on. Nevertheless, previous studies (e.g. MUSTAFA; SHORT; FAN, 2015) have demonstrated that social media constitute fertile soil for the combination of genres and, in consequence, functionality. Moreover, its unrestricted nature in terms of institutional constraints fosters a very democratic space for communication, one in which the boundaries between social purposes become blurred.

As may be noted, the configurations of meaning that constitute and define the different genres are of different dimensions, not only experiential, but also textual and interpersonal. It is the latter which constitutes our focus of concern. Narratives are not mere listings of experiences, in ideational terms; they frequently include several other elements. As has been acknowledged in the discipline from different 
traditions (see, for example, LABOV; WALETZKY, 1967; BIBER, 1995), evaluation is one of the recurrent features of narrative texts, and one of the most productive ways in which societies consolidate and transmit their values and ideologies.

Over the last decades, Martin (1992, 2004) and other scholars on the same line (MARTIN; WHITE, 2005; HOOD, 2010, among many others) have developed the System of Appraisal, a framework for the analysis of evaluative resources that unfold in texts construing "the subjective presence of writers/speakers ... as they adopt stances towards the material they present and those with whom they communicate" (MARTIN; WHITE, 2005, p. 1). Appraisal encompasses three main subsystems: Engagement, which is related to how interpersonal space is managed, including linguistic mechanisms such as the inclusion of different voices in a text; Attitude, which systematizes the resources for expressing the ways speakers feel, their judgements on others and their actions, as well as the expression of their tastes. The third subsystem of Appraisal is Graduation, which encompasses the resources for adjusting meanings of Attitude and Engagement, by intensifying them or by delineating their categorical boundaries. Although the system was initially proposed for the English language, it has proved useful for application in a variety of languages, including Spanish, which is the one under analysis in the study presented here.

For the purposes of this research, we focus of the linguistic mechanisms for the expression of Attitude, with special emphasis on Affect, since it is precisely this type of meaning which is mainly negotiated in the Facebook interactions that we analyze, and an important contribution to the social purpose that patients usually pursue when they engage in this form of communication. Though some developments have been made to the original model proposed by Martin and White (2005) by authors such as Bednarek (2008) and Ngo and Unsworth (2015), the original discourse semantic subsystem of Affect has been applied in this study, since it has been proved to clearly capture the emotive construction of feelings in texts. This subsystem includes four main domains of emotions: un/happiness, in/security, dis/satisfaction and dis/inclination.

It is worth mentioning that interpersonal meanings, like meanings of other types, are crucial in the configuration of genre. When the term is conceptualized in this approach, it encompasses textual, ideational and interpersonal meanings, which are systematically 
V. $11(3)$ 277-295 set-dez 2021

combined as texts unfold. Thus, the account of personal experiences analyzed in this study makes interpersonal meanings particularly relevant for detailed scrutiny.

It is important to mention that due to the recent and unstable nature of the discourse under analysis, we will not focus on genres, as stable configurations, but on phases, as segments in a larger unit, which, we believe, will become stable over time.

\section{Methodology}

For this study, a mixed methodology was followed on the conviction that combining approaches, methods and data collection and analysis tools and can significantly enhance the quality and understanding of the results (ELLIOTT, 2005, TASHAKKORI; TEDDLIE, 2010). Due to the large volume of texts, data delimitation, collection and analysis were conducted manually, aided by Nvivo-New (version 2020).

All comments were collected from Facebook webpages from Chile, all related to endometriosis. The following criteria were established: (a) they were Facebook pages, not groups; (b) they were all open access; (c) they had been active along the same period (January 2016 to March 2020); the number of followers was equal or higher than 750. The webpages that met all the criteria were three: Fuchen (Fundación Chilena de Endometriosis) ${ }^{2}$, Endo Chile ${ }^{3}$ and Endometriosis en Chile 4 . Ncapture for Nvivo was used to retrieve the comments. The initial date was established considering simultaneity of publication. The end date was set due to the onset of the Covid-19 pandemic, which could significantly affect the quantity and quality of the data.

Linguistic and non-linguistic data were collected. The latter category included an enormous number of graphs, emojis, emoticons, gifs and a wide variety of semiotic resources typical of this social media (SOLMAZ, 2018). In this study, we focus on resources that are linguistic since the inclusion of non-linguistic information transcends the scope of this article. The comment constituted the unit of analysis, a clearly distinctive unit in Facebook pages, that allows for a relatively easy handling of large volumes of data. The corpus was composed of 3.396 comments, with a total of 84.901 words.

\footnotetext{
${ }^{2}$ https://www.facebook.com/search/top?q=fundaci\%C3\%B3n\%20chilena\%20de\%20endometriosis ${ }^{3}$ https://www.facebook.com/search/top?q=endo\%20chile

4 https://www.facebook.com/EndometriosisEnChile
} 
Data processing was conducted manually, with the assistance of Nvivo-New for the systematization of emerging codes, nodes and classifications. The analysis consisted of three main steps. The first included the identification of comments corresponding to narratives. Then, the following elements were coded and categorized: direct and indirect coding of affect ${ }^{5}$; appraised entities (element that triggered the affect); polarity (positive or negative affect) and subtype of affect coded. Affect subtypes were classified following the proposal of the System of Appraisal (MARTIN; 2000; MARTIN; WHITE, 2005), for the dimension Affect, within the subsystem of Attitude. The third step mainly consisted in identifying the functionalities that were constructed by the comments. This was conducted taking textual as well as discourse semantic meanings involved.

\section{Results and discussion}

The analysis of the corpus revealed that, contrary to our expectations, the prevailing configuration corresponded to discourse phases other than genres in the story family. At an initial stage, stories were identified. These results are shown in Table 2.

Table 2 - Narratives vs. other phases identified in the corpus

\begin{tabular}{lcccc}
\hline & $\begin{array}{c}\text { Number (and } \\
\text { percentage) of } \\
\text { comments }\end{array}$ & $\begin{array}{c}\text { Number of } \\
\text { words }\end{array}$ & Word types & Tokens \\
\hline Stories & $488(14.3 \%)$ & 35.630 & 4.715 & 35.500 \\
\hline Other phases & $2.908(85.6 \%)$ & 49.271 & 4.727 & 34.722 \\
\hline Total corpus & $3.396(100 \%)$ & 84.901 & 8.654 & 84.712 \\
\hline Source: Author's elaboration. & & &
\end{tabular}

The stories identified consisted of texts of a variety of lengths, ranging from 34 words to detailed descriptions of the patients' experiences in 350 words. This is possible due to the unrestricted nature of Facebook comments. It is worth pointing out that even though some long narratives were identified, the average number of words per story

\footnotetext{
5 Following Martin and White's proposal, the coding of Affect may be direct, in cases in which the evaluation is explicitly inscribed in the discourse through attitudinal lexis (e.g. "I don't feel so lonely") or expressed indirectly, evoked, when the meaning is not expressed explicitly but suggested to the reader, who is "invited" to a certain interpretation (e.g. "I will not be able to be a mother" in contexts of negotiation of meanings on infertility in Latin American cultures invites the interlocutor to interpret feelings of dissatisfaction).
} 
V. 11 (3) 277-295 set-dez 2021

is 73. We hypothesize that this may result from the need to construct a story that is convincing and believable, but within the limits imposed by the immediacy and fastness of this type of interaction, in which extremely long texts tend to be ignored by readers (POELL, 2019). Following, two examples of short and long texts are included to illustrate the typical narratives found in the corpus ${ }^{6}$ :

(1) They operated on me 11 years ago and for a few months I have beenfeelingverybad again, again I am with foci of endometriosis in the intestine and with horrible pain ( $\mathrm{C} 331)^{7}$ (34 words)

(2) Hello, I have endometriosis diagnosed at the age of 30, but I have lived with it since adolescence, I was operated on for hemorrhagic appendicitis without knowing that it was the endometrium that settled in the appendix, I continued without treatment until it went to the intestine where only when operating they realized that my illness almost cost me my life. Now I am on hormonal treatment and I am no longer in danger, but adhesions remained in my lower back and in my ovaries. In the last operation they cut $15 \mathrm{~cm}$ of intestine that was necrotic and left the iliocecal valve inoperative, which prevents me from leading a normal life due to gastrointestinal problems. I was lucky, I was treated in private clinics and a private doctor treated me. I also developed an anxiety disorder due to pain. It is urgent that this disease becomes visible and that we have comprehensive support. Thank you for making the invisible visible (C62). ${ }^{8}$ (321 words)

As it may be observed, though there are expressions of support and the language is used to construct other functionalities as well, the

\footnotetext{
${ }^{6}$ Examples have been taken in their original form, so incomplete sentences, spelling and other types of uses, frequently considered "incorrect", are to be expected. Each example is preceded by the letter, which encodes the unit "comment", followed by the corresponding number in the corpus.

${ }^{7}$ Original versión in Spanish: a mi me operaron hace 11 años y desde hace unos meses me estoy volviendo a sentir muy mal, nuevamente estoy con focos de endometriosis en el intestino y con dolores horribles

${ }_{8}^{8}$ Original version in Spanish: Hola, tengo endometriosis diagnosticada a los 30 años, pero vivo con ella desde la adolescencia, fuí operada por apendicitis hemorrágica sin saber que era el endometrio que se instaló en el apéndice, seguí sin tratamiento hasta que se fue al intestino en donde solamente al operar se dieron cuenta de mi enfermedad que casi me cuesta la vida. Ahora me mantengo con tratamiento hormonal y ya no corro peligro, pero quedaron adherencias en mi zona lumbar y en mis ovarios. En la última operación me cortaron $15 \mathrm{~cm}$ de intestino que estaba necrotico y dejaron la válvula iliocecal sin funcionar lo que me impide llevar una vida normal por problemas gastrointestinales. Tuve suerte, me atendí en clínicas privadas y me trato con médico particular. Desarrolle también un trastorno de ansiedad debido al dolor. Es Urgente que está enfermedad se haga visible y que tengamos un apoyo integral. Gracias por hacer visible lo invisible.
} 
prevailing purpose of the comments is to share the speaker's personal experience. Along with variations in length, the texts present a wide variety of levels of technicality and evaluations of various entities. The prevailing ones include other patients, pain, endometriosis, treatments and motherhood (for details about types of Affect and appraised entities, see PASCUAL; DÍAZ ALEGRÍA, 2021).

Regarding the interpersonal configuration, 1.000 comments were identified and then analyzed to define their functionality. A saturation point was reached, and it determined the total of comments analyzed. There was a total of 14 different phases identified, including narratives. At this point in the analysis, they can be clearly distinguished as segments of evaluative discourse with a social purpose defined as their functionality in a more general context of the texts in which they operate. The functionalities or phases are defined as follows (Table 3).

Table 3 - Phases identified and their defining functionality

\begin{tabular}{|c|c|}
\hline Phase * & |Functionality \\
\hline $\begin{array}{l}\text { Activity report / campaign } \\
\text { / slogans }\end{array}$ & $\begin{array}{l}\text { Visibilize the disease through slogans, campaigns or } \\
\text { update members regarding the campaigns }\end{array}$ \\
\hline Advice & Give advice for the treatment of the disease \\
\hline Information exchange & $\begin{array}{l}\text { Share information through links or as plain text, } \\
\text { either external sources or own knowledge }\end{array}$ \\
\hline Mininarrative / experience & $\begin{array}{l}\text { Reference to the speaker's situations related to the } \\
\text { condition (brief accounts of experience that are } \\
\text { embedded with other functions) }\end{array}$ \\
\hline Name / highlight & $\begin{array}{l}\text { Name an individual in Facebook (using the function } \\
\text { @) to show her a post or comment }\end{array}$ \\
\hline Opinion & $\begin{array}{l}\text { Express a point of view about the condition, some } \\
\text { situation, health institutions or individuals }\end{array}$ \\
\hline Other & Corroborations ("ok", "amen", "up", etc.) \\
\hline Regret / complaint & $\begin{array}{l}\text { Express regret or complain about the condition or } \\
\text { some undesirable situation derived from the condition }\end{array}$ \\
\hline Request for action & Request action (usually request for internal messages) \\
\hline Request for information & $\begin{array}{l}\text { Request information regarding the condition, } \\
\text { experiences, doctors or health institutions }\end{array}$ \\
\hline $\begin{array}{l}\text { Support / gratefulness / } \\
\text { good intentions }\end{array}$ & Express support, gratitude or kindness \\
\hline Wish & $\begin{array}{l}\text { Construction of wishes and expectations regarding the } \\
\text { condition or health institutions }\end{array}$ \\
\hline
\end{tabular}

The phases identified, apart from narrative, are illustrated in the following examples 3-17. 
v. 11 (3)

277-295

set-dez

2021

(3) Activity report / campaign / slogans: If it hurts, it's not normal ( $\mathrm{C} 14)^{9}$

(4) Advice: you must see a specialist. So that you take tests and you can rule out what is happening $(\mathrm{C} 604)^{10}$

(5) Information Exchange: As soon as we have the oficial information we'll publish it! (C180) 11

(6) Mininarrative / experience: I went through the same and it's awful (C657) $)^{12}$

(7) Name / highlight: Look love @AAIA(C451) $)^{13}$

(8) Opinion: In my opinion doing nothing is letting it branch out and cause tumors and adhesions to other organs (C238) ${ }^{14}$

(9) Other: Hello, I tried to complete my data but could not... (C26) ${ }^{15}$

(10) Regret / complaint: people cannot imagine how much suffering we go through. More research is needed. We have to spread the word, explain. (C907) ${ }^{16}$

(11) Request for action: Hi, you could broadcast live for those of us who live in Santiago $\left(\mathrm{C}_{3} 6\right)^{17}$

(12) Request for information: Hello, I'd like to participate in the talk on the $20^{\text {th }}$. How do I go about it? (C37) ${ }^{18}$

(13) Support / gratefulness / good intentions: Let's continue fighting to make the invisible visible. A loving and affectionate greeting from Penco to all the endo warriors who struggle with this painful disease every day, and in spite of everything, we continue on. Be strong $(\mathrm{C} 14)^{19}$

\footnotetext{
9 Original version in Spanish: Si duele no es normal

${ }^{10}$ Original version in Spanish: MA debes ver un especialista. Para que te realice exámenes y puedas descartar que está sucediendo

${ }^{11}$ Original version in Spanish: Apenas tengamos la información oficial la publicaremos!

${ }^{12}$ Original version in Spanish: Yo lo pasé y es horrible

${ }^{13}$ Original version in Spanish: Mira amor @AAIA

${ }_{14}$ Original version in Spanish: en mi opinion no hacerse nada es dejar que se remifique y provoque tumores y aderencias a otros organos

${ }^{15}$ Original version in Spanish: Hola....trate de ingresar mis datos y no pude....

${ }^{16}$ Original version in Spanish: ni se imaginan lo que se sufre. Hay que investigar más. Hay que difundir, explicar

17 Original version in Spanish: hola podrían transmitir en vivo para las personas que estamos en santiago

${ }^{18}$ Original version in Spanish: Hola buenas noches me gustaria participar en la charla el dia 20 como lo puedo aser

${ }_{19}$ Original version in Spanish: A seguir luchando dia a dia para hacer visible lo invisible. Un cariñoso y afectuoso saludo desde Penco a todas las endoguerreras que dia a dia luchamos con esta dolorosa enfermedad pero a pesar de todo seguimos adelante. Fuerza
} 
(14) Wish: I would give anything for my daughter who suffers this terrible pain. I hope it works. (C858) ${ }^{20}$

It is worth observing that some comments were included in more than one category. As it is usually the case, evaluation was spread throughout all the functionalities, not only in narrations. Though more than one purpose could be noted, the functionality assigned in all cases was the prevailing practice in the comment. Once all the instances were identified, they were ordered in terms of frequency, from the most to the least frequent. The analysis of the phases of the evaluative Facebook comments rendered the following results presented in Figure 4.

Figure 4 - Phases arranged in order of frequency

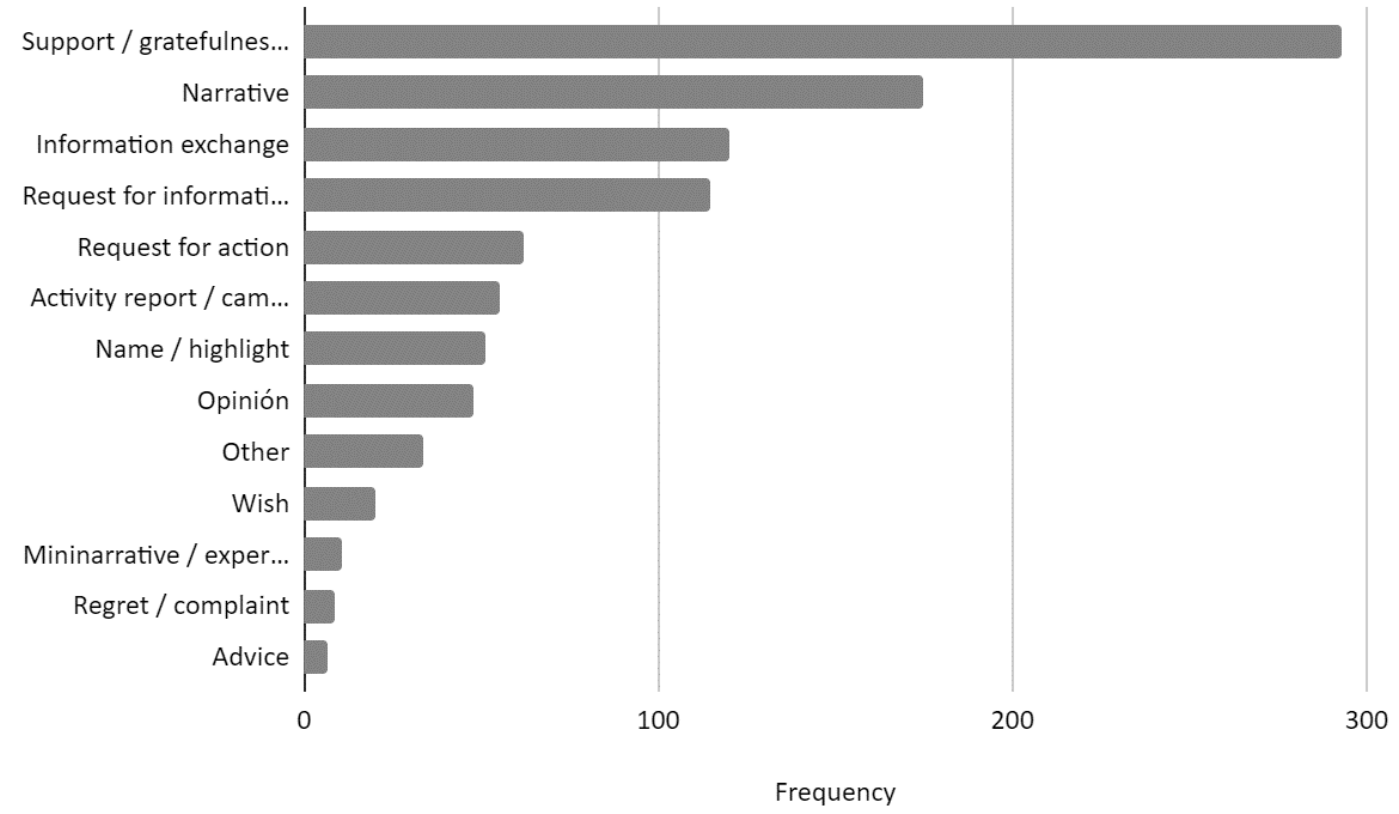

Source: Author's elaboration.

As shown in Figure 4, the predominant functionality for the comments is to provide support, gratefulness, and express good intentions. This category concentrated $29.3 \%$ of all comments, followed by the use of narratives, which represented a $17.5 \%$ of the total. It seems clear that these Facebook communities operate as support groups in a literal sense. Unlike the highly ritualistic support sessions in face-toface interactions, in which a strong emphasis was placed on sharing the personal experience of the member, after a very short introduction and only followed by the prototypical closing phase "thank you for

${ }^{20}$ Original version in Spanish: Pagaría lo que fuera por mi hija que sufre este horrible dolor ojala funcione 
V. 11 (3)

277-295

set-dez

2021

sharing", Facebook support groups are richer and far more varied in terms of the functionalities they offer.

It is worth noticing that the third and fourth functionalities identified, corresponding to $12 \%$ and $11.5 \%$ in frequency, respectively, were information exchanges, in which information was directly presented (about interviews, manifestations, health professionals and facilities, nutrition, and treatments in general) and requests for information, usually produced by women who were uncertain about their diagnoses, or lived away from cities where they could have readily access to medical institutions.

Regarding the types of values appraised, and as in the case of the most frequent phases, the interpersonal configurations related mainly to values of in-satisfaction and un-happiness, revealing high percentages of negative polarity towards certain entities such as doctors, lack of information or treatment. However, high levels of positive appraisal were constructed through all the phases, with equally high levels of satisfaction, construing basically a closely-knit fabric of members who support and appreciate the presence of the group (for a detailed description of the Appraisal resources identified, see PASCUAL; DÍAZ ALEGRÍA, 2021).

It is important to consider that even though four functionalities were predominant, accounting for $70 \%$ of the interactions, the remaining $30 \%$ also played an important role in the interaction. Such purposes included requests for action, naming (i.e. using @ followed by a name to enlarge the network), and many others. All these functionalities are part of a larger discourse, a macro-genre or system of social processes in Martin's terms (1992) which share a generalized focus on a specific activity.

\section{Final remarks}

Our objective in this study was to identify specific configurations of evaluative meanings in Facebook pages which constitute support groups for patients who suffer endometriosis. We analyzed 3.396 comments, a large number of interactions in which patients showed their worries, concerns and wishes regarding their condition and their futures. Contrary to our expectations, the data showed that patients take part in Facebook groups not for the purpose of "being heard", sharing their experiences, but mainly to become part 
of a group in which they can exchange their feelings, fears, desires and experiences with the disease, and many other types of information and feelings.

Showing membership proved to be more important than narrating the patient's experience. It seems paradoxical that digital communication is at the same time criticized for being cold and depersonalized, but also the space for patients to exchange their most intimate feelings and ideas. In this sense, Facebook has proved to be a very fertile soil for the creation and consolidation of social bonds.

The participants in this study were 99\% women, affected by a gynecological chronic condition. Future studies might focus on other conditions, one which affects women and men (such as diabetes or coronary diseases) in order to determine whether the configuration of the microgenre and its phases is similar. It may also be of interest to shed light on the specifics of this social platform in contrast with others, such as Instagram or Twitter, to identify commonalities and differences.

In a nutshell, we can safely affirm that Facebook pages provide the space for a variety and quantity of affective support that has not only replicated existing face-to-face groups, but also greatly expanded its social functionalities.

\section{References}

AGHA, A. Language and Social Relations. Cambridge University Press, Cambridge, 2007.

ANTÓN, M.; GOERING, E. Understanding Patients' Voices: A Multi-method Approach to Health Discourse, John Benjamins, Philadelphia, 2015.

BEDNAREK, M., Emotion Talk across Corpora. London/New York, Palgrave Macmillan, 2008.

BIBER, D., Dimensions of register variation: A cross-linguistic comparison. Cambridge, Cambridge University Press, 1995.

BORNAT, J. Biographical Methods, en Pentti Alasuuta, Julia Brannen y Leonard Bickman (coords.), Handbook of Social Research, London, Sage, 2008.

BULLO, S. "I feel like I'm being stabbed by a thousand tiny men": The challenges of communicating endometriosis pain. Health: An Interdisciplinary Journal for the Social Study of Health, Illness and Medicine, 2019.

BULLO, S. Exploring disempowerment in women's accounts of endometriosis experiences. Discourse \& Communication. 2018, 11(6): 1-18. 
V. 11 (3) 277-295 set-dez 2021
ELLIOTT, J. Using Narrative in Social Research: Qualitative and Quantitative Approaches, Londres, Sage; 2005.

HALLIDAY, M.A.K. An Introduction to Functional Grammar. Edward Arnold, 1985.

HALLIDAY, M.A.K. Language as social semiotic: The social interpretation of language and meaning. London: Edward Arnold, 1978.

HALLIDAY, M.A.K.; MATTHIESSEN, C. Halliday's introduction to functional grammar (4th ed.). Routledge, 2014.

HAMILTON, H.; CHOU, W.S. The Routledge Handbook of Language and Health Communication. Routledge, 2016.

HJELMSLEV, L. Prolegomena to a Theory of Language. University of Wisconsin Press, 1961.

HOOD, S. Appraising research: Evaluation in academic writing. Palgrave Macmillan, 2010.

JACOBS, R. et al. The importance of social media for patients and families affected by congenital anomalies: A Facebook cross-sectional analysis and user survey. Journal of Pediatric Surgery. 51, 11, 2016, pp.1766-1771.

KAPLAN, A.M.; HAENLEIN M. Users of the world, unite! The challenges and opportunities of social media. Business Horizons, 53(1), 2010, pp. 59-68.

KOBALL, A.M. el al. Examination of bariatric surgery Facebook support groups: a content analysis. Surg Obes Relat Dis. 2017, 13(8), pp.1369-1375.

LABOV, W.; WALETZKY, J. Narrative analysis. Essays on the Verbal and Visual Arts, ed. J. Helm, 12-44. Seattle: U. of Washington Press, 1967. Reprinted in Journal of Narrative and Life History 7, 1967, pp. 3-38.

LEPPANEN, S.; WESTINEN, E.; KYTOLA, S. Social Media Discourse, (Dis) identifications and Diversities. Routledge, 2017.

MARTIN, J.R. Grammaticalising ecology: the politics of baby seals and kangaroos. T Threadgold, E A Grosz, G Kress; M A K Halliday [Eds.] Semiotics, Ideology, Language. Sydney: Sydney Association for Studies in Society and Culture (Sydney Studies in Society and Culture 3) 1986, pp. 225-268.

MARTIN, J.R. English Text: System and structure. Amsterdam: Benjamins, 1992.

MARTIN, J.R. Beyond exchange: Appraisal systems in English. En S. HUNSTON, S., THOMPSON, G. (Eds.), Evaluation in text: Authorial stance and the construction of discourse (pp. 142-175). Oxford: Oxford University Press, 2000.

MARTIN, J.R. Mourning: how we get aligned. Discourse and Society, 15 2-3, 2004, pp. 321-344.

MARTIN, J. R.; D. ROSE. Working with Discourse. Continuum, 2007. 
MARTIN, J. R.; D. ROSE. Genre Relations: Mapping Culture. Equinox, 2008.

MARTIN, J.R.; WHITE, P.R.R. The language of evaluation. Appraisal in English. Palgrave Macmillan, 2005.

MUSTAFA, H. R.; SHORT, M., FAN, S. Social Support Exchanges in Facebook Social Support Group. Procedia - Social and Behavioral Sciences, 185, 2015, pp.346-351.

NGO, T.; UNSWORTH, L. Reworking the Appraisal Framework in ESL Research: Refining Attitude Resources. Functional Linguistics. 2015, 2, 1, pp.1-24.

PARTRIDGE, S.R. et al. Facebook Groups for the Management of Chronic Diseases. Journal of Medical Internet Research. 2018, 17;20(1): e21.

PASCUAL, M. La construcción de la evaluación en los discursos de memoria y dolor: aportes desde las intersecciones. En Métodos de Análisis del Discurso, Perspectivas argentinas. Oscar Iván Londoño Zapata; Giohanny Olave Arias (Coord.). (pp. 177-194). Ediciones de la U: Bogotá, 2019.

PASCUAL, M. Discurso, salud e información desde el relato de pacientes de endometriosis. Discurso \& Sociedad, 2020 14(2), pp. 421-442.

PASCUAL, M.; DÍAZ ALEGRÍA, N. El afecto en relatos de experiencias de dolor crónico en comentarios de Facebook de mujeres chilenas. Nueva Revista del Pacífico, 2021, 74, pp. 47-64.

POELL, T. Social media, temporality and the legitimacy of protest. Social Movement Studies, 19:5-6, 609-624, 2019.

ROSE, D. Genre in the Sydney School. In J Gee; M Handford (eds) The Routledge Handbook of Discourse Analysis. London: Routledge, 2011, pp. 209-225.

ROTHIER DUARTE, C.; BATISTA MELO, L. Discurso e adesão a páginas do facebook: uma investigação integrada sobre ethos, gênero e suporte. Âlabe 19. 2019.

SOLMAZ, O. Multilingual and Multimodal Repertoires as part of Identity Management on Facebook: A Case of International Students. Journal of International Students, 8, 4, 2018, pp. 1662-1680.

SPIEGEL, D. et al. Effect of psychosocial treatment on survival of patients with metastatic breast cancer. Lancet, 2, (8668), 888-891, 1989.

STÆHR, A. Reflexivity in Facebook interaction - Enregisterment across written and spoken language practices. Discourse, Context and Media, 8, 3045, 2015.

TASHAKKORI, A.; TEDDLIE, C. (coords.), Handbook of Mixed Methods in Social and Behavioral Research, 2a ed., Thousand Oaks, Sage, 2010.

von RAFFLER-ENGEL, W. Doctor-patient interaction. John Benjamins Publishing Company, 1989.

WODAK, R. Disorders of Discourse. London: Longman, 1996. 